\title{
Estimates of Variability for Growth and Yield Attributes in Taro (Colocasia esculenta var. Antiquorum (L.) Schott)
}

\author{
Manvendra Singh*, G.C. Yadav, Vimlesh Kumar, \\ Deepak Kumar Gautam and Akshay Jain
}

\begin{abstract}
Department of Vegetable Science, Narendra Deva University of Agriculture and Technology, Kumarganj, Faizabad-224 229 (U.P.), India

*Corresponding author
\end{abstract}

\section{A B S T R A C T}

\begin{tabular}{|l|}
\hline Key w or d s \\
Variability, \\
Heritability, \\
Taro and \\
yield per plant. \\
\hline Article Info \\
\hline $\begin{array}{l}\text { Accepted: } \\
\text { 17 June } 2017 \\
\text { Available Online: } \\
\text { 10 August } 2017\end{array}$ \\
\hline
\end{tabular}

The present investigation was carried out in two different environments with aim to assess genetic variation among the genotypes for growth, yield attributes. The present investigation was comprised forty diverse genotypes of taro. The present study revealed that the significant differences for sixteen traits among genotypes of taro which indicated that the presence of adequate variability which could be harnessed for developing yield potential cultivars. The phenotypic and genotypic coefficients of variation were high for width of leaf, weight of corms per plant, number of cormels per plant and petiole length. Moderate to high heritability was evident for all the traits and was accompanied with high genetic advance for weight of corm, girth number of cormels, weight of cormels, of corm, length of leaf, width of leaf, and petiole length which suggests the role of additive gene action and thus, a high genetic gain is expected from selection of these traits. Moreover, high heritability along with moderate genetic advance for sheath length, height of plant, reveals the presence of additive and non-additive gene action simultaneously. On the other hand, dry matter showed low genetic advance along with high heritability that reflects the presence of non-additive action.

\section{Introduction}

Taro (Colocasia esculenta var. antiquorum) is one of the oldest and most important tuber crop. It is also known as eddoes type taro, arvi and ghuia. It is grown mostly as staple or subsistence crop throughout the tropics and subtropics. Although this crops is not treated as economically important and was often considered as poor man's crop which is most extensively consumed by the low income group in the rural areas.

India to Southern Asia is the centre of origin of Colocasia from where it has travelled east to all the Island of Occeania, Phillipines, China and Japan although, India is said to the native of taro. Africa ranks first in area and production of Colocasia followed by Asia. In India, it is mainly cultivated in Eastern and Southern States - Faizabad, Varanasi, Sitapur, Sultanpur, and some parts of Jhansi etc. Deoria are the leading districts with regard to Arvi production particularly in Eastern districts of Uttar Pradesh. The objective of the present study, therefore, was to examine the variability, extent of inheritance and character association for various traits of economic importance in 40 genetically diverse 
germplasms. The result of this study could be useful in developing high yielding clones having good quality.

\section{Materials and Methods}

The experimental were comprised of forty genotype collected from All India Coordinate Research on Tuber Crops. The experiments were carried out at two location i.e. NDUAT Kumarganj, Faizabad, UP and Farmer's field Belakhra, Faizabad, UP for two consecutive seasons i.e. 2015 and 2016 in the randomized block design with three replications. Cormels of each genotype were planted in the month of March at inter and intra row spacing of 60 $\mathrm{cm}$ having plot size of: $2.40 \mathrm{~m} \times 1.80 \mathrm{~m}$. The standard packages of practices were followed to raise the crops was harvested in November.

Morphological observation were recorded on five randomly selected plants from each plot and replication for days to sprouting, length of leaf $(\mathrm{cm})$, width of leaf $(\mathrm{cm})$, girth of plant $(\mathrm{cm})$, petiole length $(\mathrm{cm})$, sheath length $(\mathrm{cm})$, height of plant $(\mathrm{cm})$, length of cormels $(\mathrm{cm})$, girth of cormels $(\mathrm{cm})$, number of cormels /plant, weight cormels /plant (g), length of corm $(\mathrm{cm})$, girth of corms $(\mathrm{cm})$, weight of corms /plant (g), dry matter (\%), yield / plant (g) were estimated.

The data were analysed for coefficient of variation (Burton and De Vane, (1953), heritability (Burton and De Vane, (1953), genetic advance (Johnson et al., 1955).

\section{Results and Discussion}

Highly significant mean squares due to genotypes for all the traits indicate the prevalence of sufficient amount of variation among genotypes which is pre -requisite for breeding of taro (Table 1). The extent of variability present in germplasm was estimated in terms of range; standard error; phenotypic, genotypic and environmental variance ( $\mathrm{Vp}, \mathrm{Vg}$ and $\mathrm{Ve}$, respectively); phenotypic and genotypic coefficient of variation (PCV and GCV) and heritability $\left(\mathrm{h}^{2}\right)$ along with genetic advance as percentage of mean. The (GCV) was maximum for weight of corms per plant (g) (24.96) followed by number of cormels (23.29) and lowest dry matter (\%) (4.12) the traits having high. The traits having high GCV possess a higher magnitude of variability and thus present a better possibility of exploitation for improvement through breeding approaches. In general, the PCV was higher than its corresponding GCV. This is because of the fact that PCV includes genotypic and environmental variation. The meagre differences between PCV and GCV for all the characters indicate less effect of environment on the phenotypic expressions. Similar results were also reported by Laxmi et al., (1980), Kumar (1995), Singh et al., (2000) and Mukharjee et al., (2003).

Heritable portion of variation can be deduced by computing the heritability and genetic advance as percentage of mean. The heritability estimates were observed to be high length of leaf $(\mathrm{cm})(92 \%)$, weight of cormels/plant $(91 \%)$, yield per plant $(88 \%)$, height of plant $(85 \%)$, width of leaf $(81 \%)$, number of cormels/ plant $(81 \%)$ and sheath length $(\mathrm{cm})(79 \%)$. Never the less, it was low for girth of plant $(\mathrm{cm})(18 \%)$ A high heritability for a trait indicates that a large portion of phenotypic variance is contributed through genotypic variance and therefore, a reliable selection can be made for these traits.

The genetic advance as percentage of mean was highest for weight of corms/plant (g) (46.41), followed by number of cormels/plant (43), length of leaf $(\mathrm{cm})$ (32), width of leaf (cm) (32.13) and petiole length $(\mathrm{cm})$ (31.06), while it was lowest for length of cormel/ plant (11.77), girth of cormels (cm) (11.54), length of corm (cm) (9.05), dry matter (\%) (5.65) and girth of plant (3.99) (Table 2). 
Table.1 Analysis of variance (ANOVA) for various traits among 40 genotypes in Colocasia over environments (Pooled)

\begin{tabular}{|c|c|c|c|c|c|c|c|c|c|}
\hline Source of & d.f. & $\begin{array}{c}\text { Days to } \\
\text { sprouting }\end{array}$ & $\begin{array}{l}\text { Length of } \\
\text { leaf }(\mathrm{cm})\end{array}$ & $\begin{array}{l}\text { Width of } \\
\text { leaf }(\mathrm{cm})\end{array}$ & $\begin{array}{c}\text { Girth of } \\
\text { plant }(\mathrm{cm})\end{array}$ & $\begin{array}{c}\text { Petiole } \\
\text { length }(\mathrm{cm})\end{array}$ & $\begin{array}{c}\text { Sheath } \\
\text { length }(\mathrm{cm})\end{array}$ & $\begin{array}{c}\text { Height of } \\
\text { Plant }(\mathrm{cm})\end{array}$ & $\begin{array}{c}\text { Length of } \\
\text { cormel }(\mathbf{c m})\end{array}$ \\
\hline Replicate & 2 & 0.15 & 3.88 & 6.20 & 0.18 & 1.56 & 0.52 & 4.11 & 0.26 \\
\hline Environments & 3 & $228.48 * *$ & 1.75 & $154.35 * *$ & $290.04 * *$ & $208.47 * *$ & $86.96 * *$ & $174.40 * *$ & $32.40 * *$ \\
\hline Interactions & 6 & 1.31 & 1.47 & 2.93 & 2.54 & 3.31 & 1.78 & 7.75 & 0.21 \\
\hline Overall Sum & 11 & $63.06 * *$ & 1.99 & $44.82 * *$ & $80.52^{* *}$ & $58.95 * *$ & $24.78 * *$ & $52.54 *$ & $9.00 * *$ \\
\hline Genotypes & 39 & $45.45 * *$ & $595.30 * *$ & $449.62 * *$ & $10.55 * *$ & $202.74 * *$ & $119.05 * *$ & $1462.28 * *$ & $5.86^{* *}$ \\
\hline Error & 429 & 2.00 & 4.54 & 8.40 & 2.92 & 5.76 & 2.56 & 21.14 & 0.86 \\
\hline
\end{tabular}

\begin{tabular}{|c|c|c|c|c|c|c|c|c|c|}
\hline Source of & d.f. & $\begin{array}{l}\text { Girth of } \\
\text { cormels } \\
(\mathrm{cm})\end{array}$ & $\begin{array}{l}\text { Number of } \\
\text { cormels } \\
\text { /Plant }\end{array}$ & $\begin{array}{l}\text { Weight of } \\
\text { cormels } \\
\text { /plant(g) }\end{array}$ & $\begin{array}{l}\text { Length of } \\
\text { corm }(\mathrm{cm})\end{array}$ & $\begin{array}{c}\text { Girth of } \\
\text { corms }(\mathrm{cm})\end{array}$ & $\begin{array}{c}\text { Weight of } \\
\text { corms/plant } \\
\text { (g) }\end{array}$ & $\begin{array}{c}\text { Dry matter } \\
(\%)\end{array}$ & Yield/Plant(g) \\
\hline Replicate & 2 & 0.26 & 1.09 & 394.75 & 0.35 & 1.86 & 181.86 & 0.07 & 663.15 \\
\hline Environments & 3 & $29.81 * *$ & $15.27^{*}$ & $4244.73 * *$ & $9.31 * *$ & $35.44 * *$ & $1077.59 * *$ & 0.05 & $6035.89 * *$ \\
\hline Interactions & 6 & 0.21 & 2.85 & 105.04 & 0.26 & 0.74 & 51.67 & 1.48 & 383.73 \\
\hline Overall Sum & 11 & $8.29 * *$ & $5.92 *$ & $1286.72 * *$ & $2.74 * *$ & 10.41 & $355.14 *$ & 0.83 & $1976.03 *$ \\
\hline Genotypes & 39 & $6.79 * *$ & $171.44 * *$ & $51351.82 * *$ & $6.12 * *$ & $71.42 * *$ & $8546.55 * *$ & $9.60 * *$ & $62537.07 * *$ \\
\hline Error & 429 & 0.86 & 3.18 & 411.56 & 0.74 & 7.81 & 158.91 & 0.91 & 727.18 \\
\hline
\end{tabular}

$*, * *$ Significant at $5 \%$ and $1 \%$ levels, respectively.

Table.2 Estimates of variability parameters for different traits in Colocasia during two environments ( $\mathrm{E}_{1}$, $\left.\mathrm{E}_{2}\right)$, two years and pooled

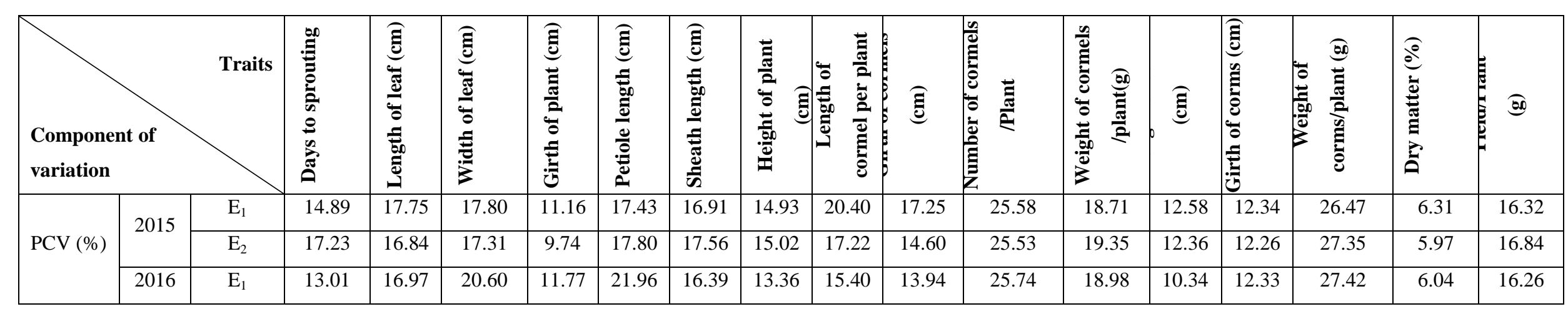


Int.J.Curr.Microbiol.App.Sci (2017) 6(8): 1282-1286

\begin{tabular}{|c|c|c|c|c|c|c|c|c|c|c|c|c|c|c|c|c|c|c|}
\hline & & $\mathrm{E}_{2}$ & 16.41 & 17.14 & 20.64 & 10.39 & 22.68 & 17.64 & 14.72 & 17.05 & 15.40 & 26.28 & 19.61 & 11.24 & 29.53 & 29.30 & 6.44 & 17.01 \\
\hline & & pooled & 15.28 & 17.18 & 19.16 & 10.83 & 20.36 & 17.15 & 14.54 & 17.50 & 15.28 & 25.80 & 19.17 & 11.62 & 18.60 & 27.65 & 6.19 & 16.61 \\
\hline \multirow{5}{*}{$\begin{array}{l}\mathrm{GCV} \\
(\%)\end{array}$} & \multirow{2}{*}{2015} & $\mathrm{E}_{1}$ & 12.60 & 17.12 & 16.62 & 6.11 & 16.53 & 15.72 & 14.40 & 15.95 & 13.49 & 23.61 & 17.94 & 9.29 & 9.32 & 24.21 & 4.31 & 15.28 \\
\hline & & $\mathrm{E}_{2}$ & 15.24 & 16.33 & 16.18 & 5.92 & 16.98 & 16.75 & 14.54 & 14.46 & 12.26 & 23.87 & 18.95 & 10.52 & 9.82 & 26.69 & 3.96 & 16.40 \\
\hline & \multirow{2}{*}{2016} & $E_{1}$ & 11.06 & 16.28 & 19.98 & 8.55 & 21.14 & 15.43 & 12.59 & 6.21 & 7.35 & 23.91 & 18.12 & 7.10 & 10.10 & 24.85 & 3.98 & 15.03 \\
\hline & & $\mathrm{E}_{2}$ & 13.68 & 16.69 & 20.06 & 7.25 & 21.92 & 17.15 & 14.13 & 13.45 & 6.21 & 24.96 & 18.82 & 8.96 & 28.81 & 28.32 & 4.40 & 16.34 \\
\hline & & pooled & 12.26 & 16.44 & 17.29 & 4.58 & 17.52 & 15.26 & 13.40 & 10.00 & 9.25 & 23.29 & 18.31 & 7.15 & 11.83 & 24.96 & 4.12 & 15.55 \\
\hline \multirow{5}{*}{$\begin{array}{l}\mathrm{ECV} \\
(\%)\end{array}$} & \multirow{2}{*}{2015} & $\mathrm{E}_{1}$ & 7.94 & 4.68 & 6.37 & 9.34 & 5.55 & 6.22 & 3.92 & 12.71 & 10.75 & 9.85 & 5.31 & 8.49 & 8.09 & 10.71 & 4.61 & 5.72 \\
\hline & & $\mathrm{E}_{2}$ & 8.02 & 4.10 & 6.16 & 7.74 & 5.34 & 5.27 & 3.75 & 9.34 & 7.92 & 9.05 & 3.96 & 6.49 & 7.35 & 5.95 & 4.47 & 3.83 \\
\hline & \multirow{2}{*}{2016} & $\mathrm{E}_{1}$ & 6.85 & 4.80 & 5.01 & 8.09 & 5.95 & 5.52 & 4.47 & 14.09 & 11.84 & 9.54 & 5.66 & 7.52 & 7.07 & 11.59 & 4.53 & 6.19 \\
\hline & & $\mathrm{E}_{2}$ & 9.06 & 3.90 & 4.85 & 7.44 & 5.81 & 4.15 & 4.13 & 10.48 & 14.09 & 8.24 & 5.51 & 6.78 & 6.49 & 7.49 & 4.71 & 4.74 \\
\hline & & pooled & 9.12 & 4.99 & 8.27 & 9.81 & 10.38 & 7.83 & 5.62 & 14.36 & 12.16 & 11.10 & 5.70 & 9.17 & 14.36 & 11.90 & 4.62 & 5.84 \\
\hline \multirow{5}{*}{$\begin{array}{c}\mathrm{h}^{2} \\
\text { (broad } \\
\text { sense) } \\
(\%)\end{array}$} & \multirow{2}{*}{2015} & $\mathrm{E}_{1}$ & 72 & 93 & 87 & 30 & 90 & 86 & 93 & 61 & 61 & 85 & 92 & 54 & 57 & 84 & 47 & 88 \\
\hline & & $\mathrm{E}_{2}$ & 78 & 94 & 87 & 37 & 91 & 91 & 94 & 71 & 71 & 87 & 96 & 72 & 64 & 95 & 44 & 95 \\
\hline & \multirow{2}{*}{2016} & $\mathrm{E}_{1}$ & 72 & 92 & 94 & 53 & 93 & 89 & 89 & 16 & 28 & 86 & 91 & 47 & 67 & 82 & 44 & 85 \\
\hline & & $\mathrm{E}_{2}$ & 69 & 95 & 94 & 49 & 93 & 94 & 92 & 62 & 16 & 90 & 92 & 64 & 95 & 93 & 47 & 92 \\
\hline & & Pooled & 64 & 92 & 81 & 18 & 74 & 79 & 85 & 33 & 37 & 81 & 91 & 38 & 40 & 81 & 44 & 88 \\
\hline \multirow{5}{*}{$\begin{array}{c}\text { Genetic } \\
\text { advance } \\
(\% \text { of } \\
\text { mean) }\end{array}$} & \multirow{2}{*}{2015} & $E_{1}$ & 21.95 & 34.03 & 31.98 & 6.89 & 32.27 & 30.12 & 28.63 & 25.69 & 21.72 & 44.89 & 35.44 & 14.12 & 14.50 & 45.61 & 6.06 & 29.48 \\
\hline & & $\mathrm{E}_{2}$ & 27.79 & 32.64 & 31.15 & 7.41 & 33.36 & 32.91 & 29.00 & 25.03 & 21.22 & 45.98 & 38.20 & 18.44 & 16.18 & 53.67 & 5.41 & 32.89 \\
\hline & \multirow{3}{*}{2016} & $\mathrm{E}_{1}$ & 19.36 & 32.16 & 39.92 & 12.79 & 41.92 & 29.93 & 24.43 & 5.16 & 7.99 & 45.74 & 35.62 & 10.05 & 17.05 & 46.39 & 5.42 & 28.63 \\
\hline & & $\mathrm{E}_{2}$ & 23.48 & 33.48 & 40.16 & 10.42 & 43.65 & 34.33 & 27.93 & 21.86 & 5.16 & 48.82 & 37.20 & 14.72 & 57.90 & 56.41 & 6.19 & 32.32 \\
\hline & & Pooled & 20.26 & 32.40 & 32.13 & 3.99 & 31.06 & 27.97 & 25.46 & 11.77 & 11.54 & 43.31 & 36.01 & 9.05 & 15.50 & 46.41 & 5.65 & 29.98 \\
\hline \multirow{5}{*}{$\begin{array}{c}\text { General } \\
\text { Mean }\end{array}$} & \multirow{2}{*}{2015} & $\mathrm{E}_{1}$ & 42.80 & 35.07 & 15.47 & 21.92 & 19.24 & 81.37 & 6.25 & 7.39 & 7.39 & 16.04 & 353.65 & 9.03 & 18.93 & 107.11 & 20.63 & 460.77 \\
\hline & & $\mathrm{E}_{2}$ & 14.28 & 42.77 & 34.99 & 16.89 & 22.05 & 20.39 & 82.85 & 6.35 & 7.49 & 15.78 & 350.23 & 9.27 & 19.33 & 101.96 & 20.67 & 452.19 \\
\hline & \multirow{2}{*}{2016} & $\mathrm{E}_{1}$ & 16.88 & 42.64 & 33.73 & 18.33 & 24.24 & 20.84 & 80.23 & 7.21 & 8.33 & 15.90 & 355.51 & 9.65 & 19.37 & 109.03 & 20.64 & 464.54 \\
\hline & & $\mathrm{E}_{2}$ & 14.38 & 42.53 & 36.50 & 18.95 & 24.29 & 21.20 & 82.58 & 6.02 & 7.21 & 16.59 & 364.19 & 9.54 & 20.22 & 105.56 & 20.67 & 468.88 \\
\hline & & Pooled & 15.52 & 42.69 & 35.07 & 17.41 & 23.12 & 20.42 & 81.76 & 6.46 & 7.60 & 16.08 & 355.90 & 9.37 & 19.46 & 105.92 & 20.65 & 461.60 \\
\hline
\end{tabular}

1285 
The heritability estimates together with genetic advance are usually more reliable than either of these two parameters alone in predicting the result effects. In the present study, a high heritability accompanied with a high genetic advance for weight of corms/plant, number of cormels/plant, length of leaf, width of leaf, petiole length suggests the role of additive gene action and thus, a high genetic gain is expected from selection is expected from selection of these traits. The result is in line with the finding of Rai et al., (2003), Singh et al., (2003) and Singh et al., (2004). Moreover, high heritability along with moderate genetic advance for sheath length, height of plant, days to sprouting and girth of corms reveals the presence of additive and non-additive gene action simultaneously. The moisture content showed low genetic advance along with high heritability reflects the presence of non- additive action.

\section{References}

Burton, G.W. and de Vane, D.H. (1953). Estimating heritability in tall fescue (Festuca arundinacea) from replicated clonal material. Agron. J. 4: 7881.

Johnson, H.W., Robinson, H.F. and Comstock, R.E. (1955). Estimates of genetic and environment variability in soybean. Agron. J. 47: 314-418.

Kumar, R.; Singh, V.N. and Jain, V.P. (1995). Genetic variability studies in colocasia [Colocasia esculenta (L) Schott ]. J. Root Crops 21(2): 116-118.

Lakshmi, K.R. and Amma, C.S. (1980). Studies on variability and correlation in Asian greater yam (Dioscorea alata L.). J. Root Crops 6(1): 29-32.

Mukherjee, D., Chattopadhyay, A., Rao, L.L.T. P., Satapathy, M.R. and Sen., H. (2003). Genetic variability and casual relationship in dasheen taro. Ann. Agril. Res. 24 (3):593-597.

Rai, N., Yadav, D.S., Sharma, P., and Yadav, R.K. (2003). Correlation, path coefficient and genetic variability analysis for yield and its components in colocasia. J. Root Crops 29(1): 24-28.

Singh, V.; Singh, P.K.; Kumar, K.; Shahi, B.P. and Dwivedi, S.V. (2003). Genetic variability, heritability and genetic advance for yield and its attributing traits in arvi (Colocasia esculenta var antiquorum). Indian J. Hort. 60(4): 376380.

Singh, V.B., Singh, A., Singh, P.K. and Gnash, D. (2004). Genetic variability in banda (colocasia esculenta). Indian J. Hill Farming 17 (1\&2): 128-130.

\section{How to cite this article:}

Manvendra Singh, G.C. Yadav, Vimlesh Kumar, Deepak Kumar Gautam and Akshay Jain. 2017. Estimates of Variability for Growth and Yield Attributes in Taro (Colocasia esculenta var. Antiquorum (L.) Schott). Int.J.Curr.Microbiol.App.Sci. 6(8): 1282-1286.

doi: https://doi.org/10.20546/ijcmas.2017.608.155 